\title{
Enolase-like protein present on the outer membrane of Pseudomonas aeruginosa binds plasminogen
}

\author{
Ireneusz Ceremuga • Ewa Seweryn - Iwona Bednarz-Misa • \\ Jadwiga Pietkiewicz • Katarzyna Jermakow • \\ Teresa Banaś • Andrzej Gamian
}

Received: 2 January 2013 / Accepted: 18 February 2014 /Published online: 27 March 2014

(C) The Author(s) 2014. This article is published with open access at Springerlink.com

\begin{abstract}
Pseudomonas aeruginosa is one of the pathogenic bacteria which utilize binding of the host plasminogen (Plg) to promote their invasion throughout the host tissues. In the present study, we confirmed that $P$. aeruginosa exhibits binding affinity for human plasminogen. Furthermore, we showed that the protein detected on the cell wall of $P$. aeruginosa and binding human plasminogen is an enolase-like protein. The hypothesis that alpha-enolase, a cytoplasmatic glycolytic enzyme, resides also on the cell surface of the bacterium was supported by electron microscopy analysis. The plasminogenbinding activity of bacterial cell wall outer membrane enolaselike protein was examined by immunoblotting assay.
\end{abstract}

\section{Introduction}

Pseudomonas aeruginosa, a widespread opportunistic pathogen, belongs to the Gram-negative non-fermenting bacteria of Pseudomonadaceae family. It is an etiologic agent of several respiratory, urinary, and gastrointestinal infections. Out of several known factors determining its pathogenicity, the exopolysaccharide mucus (glycocalyx) seems to be of greatest importance. It plays a prime role in cellular adhesion and persistent bacterial colonization of the epithelium and other cells. Furthermore, it exhibits immunogenic properties. $P$. aeruginosa secretes a number of cytotoxic exoenzymes,

I. Ceremuga $(\bowtie) \cdot$ E. Seweryn $\cdot$ I. Bednarz-Misa $\cdot$ J. Pietkiewicz

T. Banaś $\cdot$ A. Gamian

Department of Medical Biochemistry, Wroclaw Medical University,

Chalubinskiego 10, 50-368 Wroclaw, Poland

e-mail: ireneusz.ceremuga@am.wroc.pl

\section{K. Jermakow}

Department of Microbiology, Wroclaw Medical University,

Chalubinskiego 4, 50-368 Wroclaw, Poland such as phospholipid-cleaving phospholipase $\mathrm{C}$ and proteases degrading the host's proteins (Lomholt et al. 2001). The bacterium is particularly dangerous for immunocompromised individuals. Scientific reports suggest $P$. aeruginosa as the most important pathogen and causal agent of chronic pulmonary infections in patients with cystic fibrosis, which leads to gradual and eventually fatal decline in pulmonary function (Govan and Deretic 1996). P. aeruginosa shows low susceptibility to many classes of antibiotics (Hancock and Speert 2000; Jo et al. 2003). Immunoprophylaxis and immunotherapy (vaccines for the immunocompromised and passive immunization with hyperimmune sera) are the most promising and therefore of highest interest. Over many years, efforts to produce effective vaccines against $P$. aeruginosa were focused on two factors playing an important role in the bacterial pathogenicity: carbohydrate structures represented by lipopolysaccharides and polysaccharides of the bacterial cellular capsules and proteinaceous components of their external membranes (Campbell et al. 1996; Kim et al. 2000). Vaccines based on the latter proved safer due to higher tolerance by humans (Larbig et al. 2001; Doring and Pier 2008). The process of host colonization and further development of infection rely on the proteins of the bacterial external cellular membrane. The proteins interacting with the host's tissues initiate the degradation of physiological functions of the invaded organism, stimulate the progression of infection, and facilitate adaptation to the external environment (Lang 2000; Lin et al. 2002). The proteins exposed on the cellular membrane exhibit similar characteristics; however, it remains unclear whether they determine the course of infection. Most probably, these proteins possess auxiliary function. Enolase is a glycolytic enzyme present in eukaryotes and prokaryotes (Seweryn et al. 2007, 2009). In humans, besides catalyzing glycolysis and gluconeogenesis, it composes membranes of epithelial and endothelial cells, monocytes, leucocytes, and 
neutrophiles where it acts as a receptor of human plasminogen (Pancholi and Fischetti 1998; Pancholi 2001; Lopez-Alemany et al. 2003; Diaz-Ramos et al. 2012). Plasminogen plays a crucial role in maintaining coagulation homeostasis. Converted into active plasmin, which in turn degrades fibrin, it allows the white blood cells to migrate to the site of inflammation. The presence of protein receptors of plasminogen on the cellular surface enables the invasive bacteria to employ the fibrinolytic activity of plasmin and thus cleave the laminin, fibronectin, proteoglycans, and other components of human extracellular matrices (Kinloch et al. 2005; Agarwal et al. 2008). The ability to transmigrate through the layers of pulmonary epithelium and vascular endothelium allows the bacteria to breach the tissue barrier and colonize the host's tissues.

\section{Materials and methods}

Obtaining and purification of the enolase-like surface protein from $P$. aeruginosa cells

P. aeruginosa cells were cultured on tryptic soy agar (TSA) solid medium for $48 \mathrm{~h}$ at the temperature of $37{ }^{\circ} \mathrm{C}$. The bacterial mass $(18.7 \mathrm{~g})$ was washed with $\mathrm{pH} 7.2,10 \mathrm{mmol} / \mathrm{L}$ Tris-HCl buffer with $3 \mathrm{mmol} / \mathrm{L} \mathrm{MgSO}_{4}, 1 \%$ glycerol, and $0.5 \mathrm{mmol} / \mathrm{L}$ beta-mercaptoethanol and suspended in three volumes of the same buffer containing also $4 \mu \mathrm{g} / \mathrm{mL}$ phenylmethylsulfonyl fluoride (PMSF) and $0.2 \mu \mathrm{L} / \mathrm{mL}$ aprotinin and was frozen in $-80{ }^{\circ} \mathrm{C}$. The purity of the culture was assessed by microscopy and on agar plates. The separation of cellular structures was achieved with two freeze/thaw cycles at $-80{ }^{\circ} \mathrm{C}$ and room temperature. The sonicated material was suspended in the following buffer: $10 \mathrm{mmol} / \mathrm{L}$ Tris-Cl, $\mathrm{pH} 7.2$, with $1 \%$ glycerol, $3 \mathrm{mmol} / \mathrm{L} \mathrm{MgSO}_{4}, 0.5 \mathrm{mmol} / \mathrm{L}$ beta-mercaptoethanol, $4 \mu \mathrm{g} / \mathrm{mL}$ PMSF, and $0.2 \mu \mathrm{L} / \mathrm{mL}$ aprotinin. Undisrupted cells were removed by centrifugation at $4,000 \mathrm{~g}$, for $40 \mathrm{~min}$ at $4{ }^{\circ} \mathrm{C}$. The resulting supernatant was centrifuged at $120,000 \mathrm{~g}$ for $1 \mathrm{~h}$ at $4{ }^{\circ} \mathrm{C}$ in order to separate the membrane fraction (precipitate) from the cytosolic one (supernatant). The precipitate containing the membrane fraction (external and cytoplasmic membranes) was extracted twice in the following buffer $\mathrm{A}: 10 \mathrm{mmol} / \mathrm{L}$ Tris- $\mathrm{Cl}, \mathrm{pH} 7.2$, with $1 \%$ glycerol, $3 \mathrm{mmol} / \mathrm{L} \mathrm{MgSO}_{4}, 1 \mathrm{mmol} / \mathrm{L}$ betamercaptoethanol, and $2 \%$ Triton X-100, for $30 \mathrm{~min}$ at $20{ }^{\circ} \mathrm{C}$ and centrifuged $\left(120,000 \mathrm{~g}\right.$ for $1 \mathrm{~h}$ at $\left.4{ }^{\circ} \mathrm{C}\right)$. Next, in order to rinse off proteins of external membranes, the precipitate was extracted twice with buffer A containing $5 \mathrm{mmol} / \mathrm{L}$ EDTA (buffer B) for $30 \mathrm{~min}$ at $20^{\circ} \mathrm{C}$ and centrifuged $(120,000 \mathrm{~g}$ for $1 \mathrm{~h}$ at $4{ }^{\circ} \mathrm{C}$ ). The obtained supernatants from both extractions were combined in buffer $\mathrm{B}$ and dialyzed into the following buffer: $10 \mathrm{mmol} / \mathrm{L}$ Tris-Cl, pH 7.0, with $3 \mathrm{mmol} / \mathrm{L} \mathrm{MgSO}_{4}$ and $1 \mathrm{mmol} / \mathrm{L}$ beta-mercaptoethanol, and subsequently concentrated by lyophilization. The obtained membrane proteins were incubated once for $5 \mathrm{~min}$ at $100{ }^{\circ} \mathrm{C}$ with a reducing buffer $(50 \mathrm{mmol} / \mathrm{L}$ Tris- $\mathrm{HCl}(\mathrm{pH} 6.8), 20 \%$ glycerol, $5 \%$ sodium dodecyl sulfate (SDS), $0.005 \%$ bromophenol blue, $10 \%$ beta-mercaptoethanol) in the proportion 1:5 and separated with the Prep-Cell 491 device (Bio-Rad) in polyacrylamide gel gradient: $50 \mathrm{~mL}$ of $10 \%$ and $35 \mathrm{~mL}$ of $12 \%$ separating gel with $20 \mathrm{~mL}$ of $4 \%$ condensing gel. The proteins were separated at $250 \mathrm{~V}$ and $4{ }^{\circ} \mathrm{C}$ in an electrode buffer: $25 \mathrm{mmol} / \mathrm{L}$ Tris- $\mathrm{HCl}$ and $0.192 \mathrm{~mol} / \mathrm{L}$ glycine, $\mathrm{pH} 8.3$, with $0.5 \%$ SDS. Protein elution with the electrode buffer was started once the bromophenol blue reached the basis of the separating gel. Collected at the rate of $0.75 \mathrm{~mL} / \mathrm{min}, 1.3-\mathrm{mL}$ fractions were subsequently poured into deionized water and concentrated by lyophilization.

Immunoblotting identification of the enolase-like protein

The bacterial enolase-like protein was detected with rabbit anti-human alpha-enolase antibodies obtained in our laboratory (data not shown). Once separated in polyacrylamide gel, the proteins were transferred to the Immobilon P membrane. The transfer followed Witkowska's guidelines (Witkowska et al. 2005) in a transfer buffer $(10 \mathrm{mmol} /$ L Tris, $150 \mathrm{mmol} / \mathrm{L}$ glycine, $20 \%$ methanol) for $120 \mathrm{~min}$ at $200 \mathrm{~mA}$. After the transfer, the membrane was rinsed with water thrice in order to remove buffer traces and stained with $0.005 \%$ Ponceau $\mathrm{S}$ in $3 \%$ trichloroacetate with the aim to assess the quality of protein separation and transfer. The membrane was washed with deionized water. The membranes containing transferred proteins were incubated at $37{ }^{\circ} \mathrm{C}$ for $1 \mathrm{~h}$ with rabbit anti-human alpha-enolase antibodies diluted 1:1,000 in TBS-T $(20 \mathrm{mmol} / \mathrm{L}$ Tris- $\mathrm{HCl}, \mathrm{pH} 7.0$, with $50 \mathrm{mmol} / \mathrm{L} \mathrm{NaCl}$ and $0.05 \%$ Tween-20) with $1 \%$ bovine serum albumin (BSA). Unbound antibodies were washed off with TBS $(20 \mathrm{mmol} / \mathrm{L}$ Tris-HCl, $\mathrm{pH} 7.0$, with $50 \mathrm{mmol} / \mathrm{L} \mathrm{NaCl}$ ). Next, the membrane was incubated at $37{ }^{\circ} \mathrm{C}$ for $1 \mathrm{~h}$ with goat anti-rabbit IgG antibodies coupled with peroxidase.

Evaluation of enzymatic activity of surface proteins of $P$. aeruginosa

Surface proteins of undisrupted cells were evaluated for enolase-specific enzymatic activity as described by Pancholi (Pancholi and Fischetti 1998). The evaluation was made on bacterial cells in the phase of exponential growth. The bacteria (counted according to McFarland's scale concentration, 1.95× $10^{10}$ per milliliter) were washed thrice with a reaction buffer (100 mmol/L HEPES/NaOH, pH 7.2, with $10 \mathrm{mmol} / \mathrm{L}$ $\mathrm{MgSO}_{4}$ and $7.7 \mathrm{mmol} / \mathrm{L} \mathrm{KCl}$ ) and suspended in different 
Scheme 1 Isolation of outer membrane proteins from Pseudomonas aeruginosa

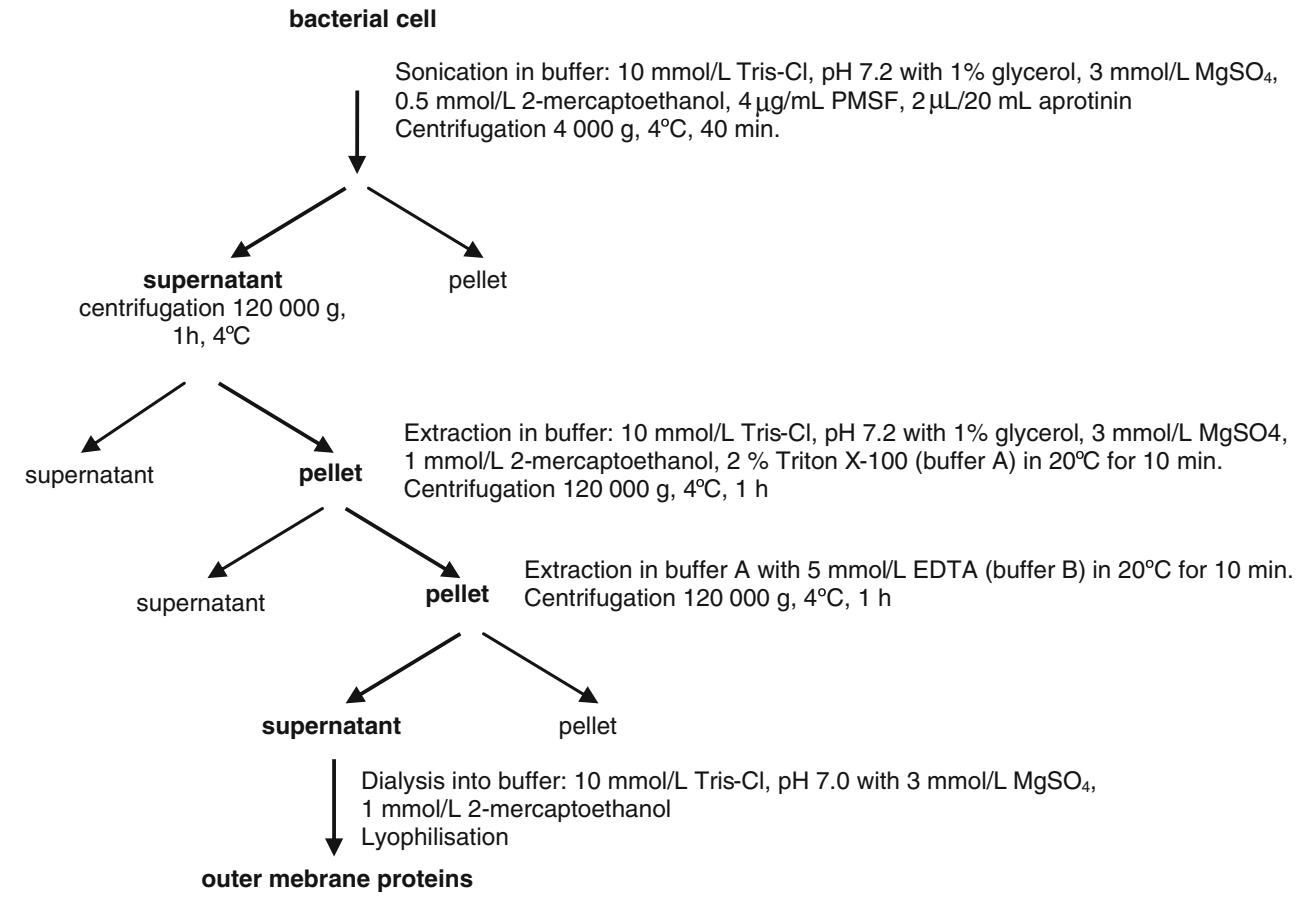

Sonication in buffer: $10 \mathrm{mmol} / \mathrm{L}$ Tris- $\mathrm{Cl}, \mathrm{pH} 7.2$ with $1 \%$ glycerol, $3 \mathrm{mmol} / \mathrm{L} \mathrm{MgSO}_{4}$, $0.5 \mathrm{mmol} / \mathrm{L}$ 2-mercaptoethanol, $4 \mu \mathrm{g} / \mathrm{mL}$ PMSF, $2 \mu \mathrm{L} / 20 \mathrm{~mL}$ aprotinin Centrifugation $4000 \mathrm{~g}, 4^{\circ} \mathrm{C}, 40 \mathrm{~min}$

$1 \mathrm{mmol} / \mathrm{L} 2$-mercaptoethanol, $2 \%$ Triton $\mathrm{X}-100$ (buffer A) in $20^{\circ} \mathrm{C}$ for $10 \mathrm{~min}$. Centrifugation $120000 \mathrm{~g}, 4^{\circ} \mathrm{C}, 1 \mathrm{~h}$

Extraction in buffer A with $5 \mathrm{mmol} / \mathrm{L}$ EDTA (buffer B) in $20^{\circ} \mathrm{C}$ for $10 \mathrm{~min}$. $Y_{\text {pellet }}$ $\mathrm{mmol} / \mathrm{L}$ 2-mercaptoethano

outer mebrane proteins concentrations in $10 \mathrm{~mL}$ of reactive buffer. Enolase substrate 2-phosphoglycerate (2-PGA) was added to the samples at 6$\mathrm{mmol} / \mathrm{L}$ concentration. For control, the bacteria were incubated under identical conditions without the substrate. The product accumulation phosphoenolpyruvate (PEP) was assessed at $37^{\circ} \mathrm{C}$ after 3-min-long incubation; the reaction was terminated by centrifugation $(10,000 \mathrm{~g}$ for $1 \mathrm{~min})$. The amount of product in the resulting supernatant was assessed by spectrometry at $240 \mathrm{~nm}$. For positive control, human $\alpha$-enolase ( $5 \mu \mathrm{g}$ in $1 \mathrm{~mL}$ of reaction buffer) was incubated for $3 \mathrm{~min}$ with 2-PGA (6 $\mathrm{mmol} / \mathrm{L})$ and without substrate.
In vitro study of interaction between the enolase-like surface protein and human plasminogen

Binding of human plasminogen by $P$. aeruginosa surface enolase-like protein was assessed by immunoblotting. After SDS-PAGE electrophoresis, the protein was transferred to a PVDF membrane. Next, the membrane was incubated with $10 \mu \mathrm{g}$ of plasminogen in $2 \mathrm{~mL}$ of TBS at $37^{\circ} \mathrm{C}$ for $1 \mathrm{~h}$. Unbound plasminogen was washed off with TBS. A control assay was carried out with rabbit anti-human plasminogen antibodies instead of anti-alpha-enolase antibodies.
Fig. 1 SDS-polyacrylamide gel electrophoresis (a) and immunoblot (b) of enolase-like protein. 1 molecular mass protein standards, 2 purified human $\alpha$ enolase from the kidney $(5 \mu \mathrm{g}), 3$ outer membrane proteins after extraction $(150 \mu \mathrm{g}), 4$ enolaselike protein after preparative electrophoresis $(10 \mu \mathrm{g})$
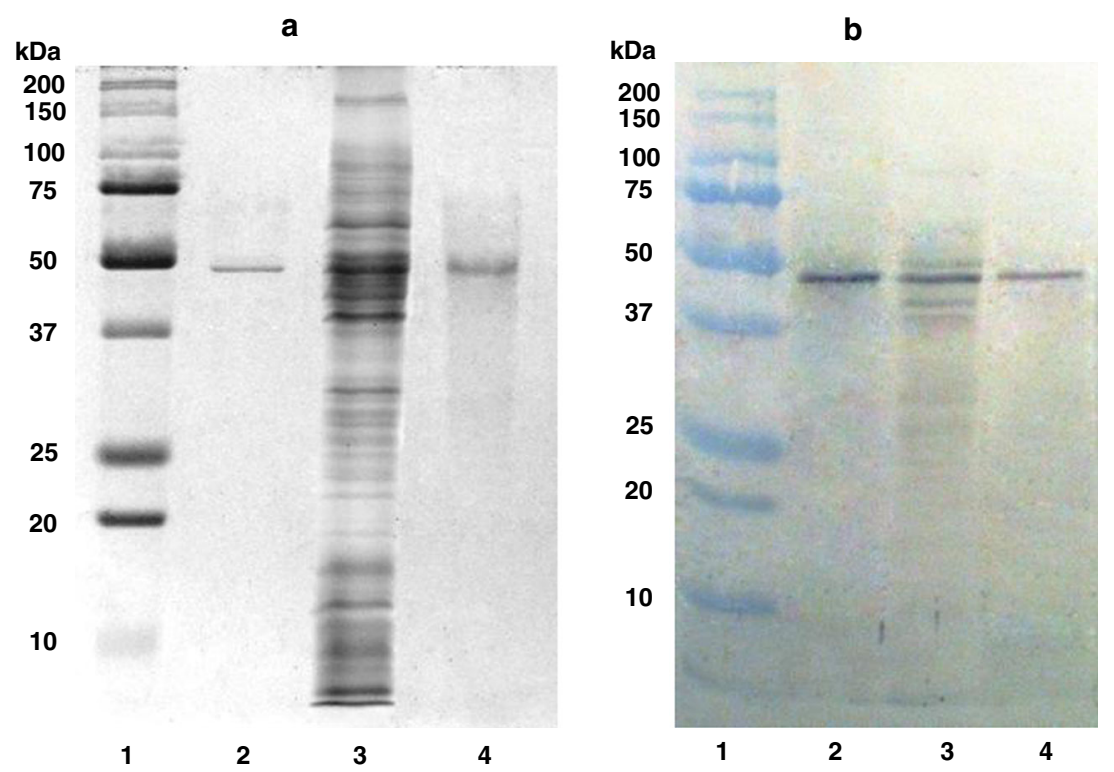
Localization of enolase-like surface receptors of $P$. aeruginosa cells by electron microscopy

The $P$. aeruginosa cells (24-h-long culture in tryptic soy broth (TSB) liquid medium) were washed off thrice with phosphatebuffered saline (PBS) by centrifugation $(5,000 \mathrm{~g}$ for $10 \mathrm{~min}$ at $4{ }^{\circ} \mathrm{C}$ ). The pellet was blocked with $1 \%$ BSA in $500 \mu \mathrm{L}$ of PBS for 30 min at $25^{\circ} \mathrm{C}$. The precipitate of bacterial cells was subjected to immunocytochemical reaction with rabbit antialpha-enolase polyclonal antibodies with $1 \%$ BSA for $12 \mathrm{~h}$. Unbound antibodies were rinsed off with PBS by centrifugation (thrice at $5,000 \mathrm{~g}$ for $10 \mathrm{~min}$ at $4{ }^{\circ} \mathrm{C}$ ); next, a marker was added-18-nm colloidal gold conjugated with goat anti-rabbit $\operatorname{IgG}$ polyclonal antibodies diluted 1:10 in PBS with $1 \%$ of BSA. After a 3-h incubation at $25{ }^{\circ} \mathrm{C}$, the excess of antibodies was washed off (thrice with PBS), and $10 \%$ BSA was added to the pellet in $1: 2$ dilution for $2 \mathrm{~h}$ at $4{ }^{\circ} \mathrm{C}$. Next, $10 \%$ formalin was added in 1:10 dilution. Once incubated for $1 \mathrm{~h}$ at $4{ }^{\circ} \mathrm{C}, P$. aeruginosa cells underwent dehydration in a series of alcohol/acetone baths. Once dehydrated and saturated with Epon 812 and DMP-30 catalyst, the sample was polymerized at $60{ }^{\circ} \mathrm{C}$ for 10 days. The blocks were sliced with an ultramicrotome, stained with toluidine blue and evaluated under JEOL 1011 transmission electron microscope.

Electron microscopy assay of plasminogen binding by $P$. aeruginosa cells

P. aeruginosa cells (a 24-h culture in TSB liquid medium) were rinsed off thrice with PBS by centrifugation at 5,000 $\mathrm{g}$ for $10 \mathrm{~min}$ at $4{ }^{\circ} \mathrm{C}$. The pellet was incubated with $30 \mu \mathrm{g}$ of plasminogen in $250 \mu \mathrm{g}$ PBS; next, the unbound protein was rinsed off thrice with PBS by centrifugation at 5,000 $\mathrm{g}$ for $10 \mathrm{~min}$ at $4{ }^{\circ} \mathrm{C}$. Once blocked with $1 \%$ BSA in $500 \mu \mathrm{L}$ PBS for $30 \mathrm{~min}$ at $25^{\circ} \mathrm{C}$, the sample was washed off thrice with PBS by centrifugation at $5,000 \mathrm{~g}$ for $10 \mathrm{~min}$ at $4{ }^{\circ} \mathrm{C}$. The sediment of bacterial cells underwent immunocytochemical reaction with rabbit anti-alpha-enolase polyclonal antibodies diluted 1:10 in PBS with 1\% BSA for $12 \mathrm{~h}$. The unbound antibodies were washed off with PBS by centrifugation at $5,000 \mathrm{~g}$ for $10 \mathrm{~min}$ at $4{ }^{\circ} \mathrm{C}$.

\section{Results}

Purification of the enolase-like surface protein

from $P$. aeruginosa cells

The purification method of $P$. aeruginosa surface enolase-like protein involved the use of sonication, extraction, and preparative electrophoresis. The first step of isolating the surface
Table 1 Purification result of enolase-like outer membrane protein from 18.7-g bacterial mass of Pseudomonas aeruginosa

\begin{tabular}{llll}
\hline & Steps & Protein mass (mg) & Yield (\%) \\
\hline 1 & Cell extract & 6,350 & 100 \\
2 & $\begin{array}{c}\text { EDTA extraction, dialysis, } \\
\text { and lyophilization }\end{array}$ & 547.8 & 8.62 \\
3 & $\begin{array}{l}\text { Preparative electrophoresis } \\
\text { Prom }\end{array}$ & 6.43 & 0.101 \\
\hline
\end{tabular}

proteins was sonication of bacteria suspended in a buffer containing a protease inhibitor. Next, the undisrupted cells were removed by centrifugation, and the resulting supernatant was ultracentrifuged with the aim to separate the cellular membrane fraction from the cytosolic one. The resulting sediment contained protein fractions bound to external and cytoplasmic membranes. After undergoing extraction cycles in detergent buffers containing a complexing compound (as in Scheme 1), a mixture of $P$. aeruginosa external membrane proteins was received (Fig. 1, row 3). Preparative electrophoresis for separation of membrane proteins and immunoblotting assay for detection allowed obtaining a purified membrane protein of electrophoretic mobility of $47 \mathrm{kDa}$ and high reactivity with anti-alpha-enolase antibodies. Figure 1a shows the purification level after successive isolation stages, while Fig. $1 \mathrm{~b}$ depicts the reaction between the purified protein and antibodies. Table 1 presents the protein purification balance.

Enzymatic activity of surface proteins of $P$. aeruginosa

Undisrupted cells of clinical strain resuspended in reactive buffer were used to determine the enzymatic activity of the bacterial enolase-like surface protein. Under these conditions, no cell lysis was observed. Following incubation of the bacteria with substrate (2-PGA), the absorbance was measured and compared with the control. The obtained results suggest that the enolase-like surface protein of $P$. aeruginosa does not exhibit enzymatic enolase activity (Table 2). Also, no enolase enzymatic activity was detected among the cytosolic fraction proteins.

Table 2 Enolase activity of outer membrane proteins of intact Pseudomonas aeruginosa cells

\begin{tabular}{lrrr}
\hline Dilution of intact bacterial cells & Control $\left(A_{240}\right)$ & Test $\left(A_{240}\right)$ & $\Delta A_{240}$ \\
\hline $1: 1$ & $0.319 \pm 0.014$ & $0.325 \pm 0.017$ & 0.006 \\
$1: 2$ & $0.281 \pm 0.012$ & $0.283 \pm 0.013$ & 0.002 \\
$1: 4$ & $0.207 \pm 0.022$ & $0.216 \pm 0.021$ & 0.009 \\
$1: 8$ & $0.189 \pm 0.019$ & $0.199 \pm 0.021$ & 0.010 \\
$1: 16$ & $0.193 \pm 0.016$ & $0.194 \pm 0.013$ & 0.001 \\
$\alpha$-Enolase & $0.089 \pm 0.015$ & $1.06 \pm 0.051$ & 0.967 \\
\hline
\end{tabular}


Fig. 2 Interaction of enolase-like protein with plasminogen. 1 molecular mass protein standards, 2 purified human $\alpha$-enolase $(10 \mu \mathrm{g}), 3$ purified enolase-like protein $(10 \mu \mathrm{g})$. a Immunoblot with anti- $\alpha$-enolase antibodies. b Immunoblot with anti- $\alpha$-enolase antibodies after reaction with plasminogen. c Immunoblot with anti-plasminogen antibodies after reaction with plasminogen a

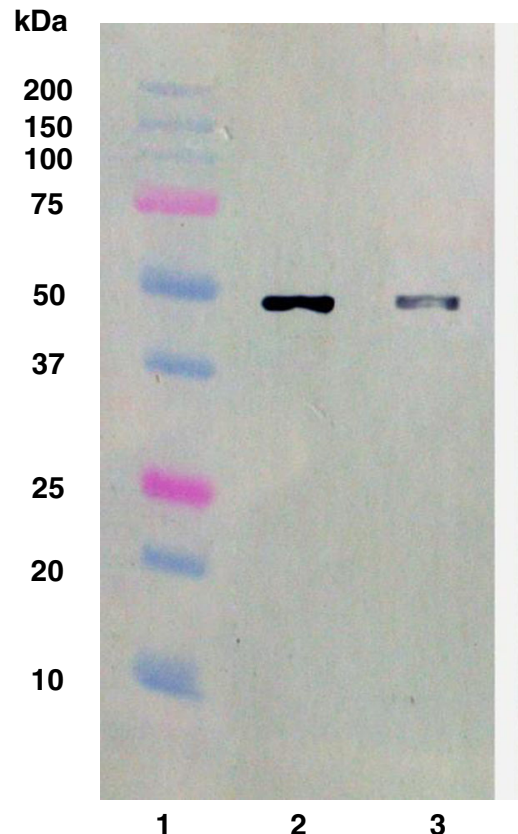

b

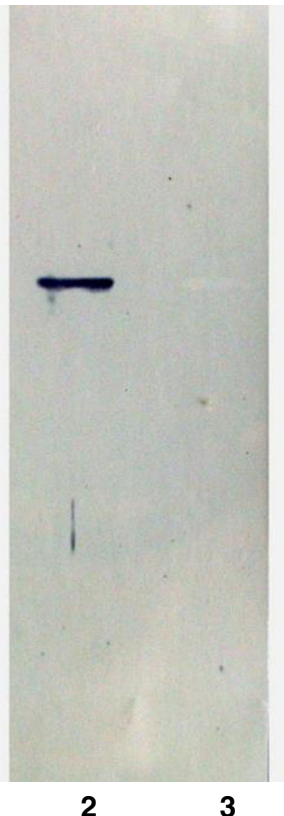

C

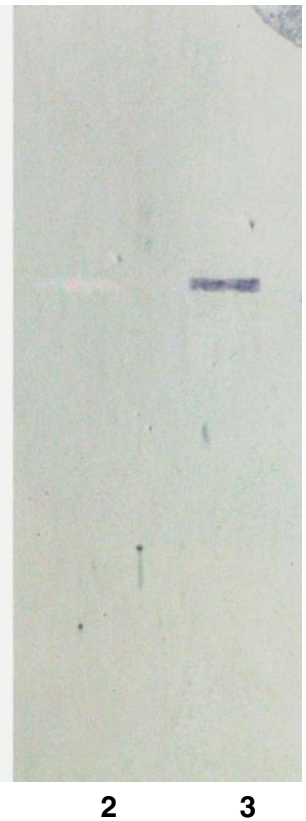

Interaction between the enolase-like surface protein and human plasminogen

Immunoblotting assay allowed assessment of the plasminogen-binding capacity of the enolase-like membrane protein. Following electrophoresis, human alpha-enolase from the kidney and membrane enolase-like protein of $P$. aeruginosa were transferred to the Immobilon $P$ membrane. Both proteins exhibited reactivity with rabbit anti-alpha-enolase polyclonal antibodies (Fig. 2a). The immunoblots, blocked with plasminogen and then treated with anti-alpha-enolase polyclonal antibodies, revealed that $P$. aeruginosa membrane enolase-like protein bound plasminogen and thus did not form complexes with antibodies (Fig. 2b, row 3); however, no such interaction has been observed in the case of alpha-enolase from the human kidney (Fig. 2b, row 2). These results were confirmed by an immunoblot incubated with plasminogen and subsequently developed with anti-plasminogen antibodies (Fig. 2c).

Localization of enolase-like surface receptors of $P$. aeruginosa cells

Electron microscopy assay with the use of goat anti-rabbit IgG antibodies conjugated with 18-nm colloidal gold allowed localizing the enolase-like surface protein. The rabbit antihuman alpha-enolase polyclonal antibodies bind to the enolase-like protein on the bacterial surface (Fig. 3a). However, bacterial cells blocked with human plasminogen did not express any reaction with rabbit anti-human alpha-enolase polyclonal antibodies. No complex forming with antibodies conjugated with colloidal gold was observed in the sample (Fig. 3b).

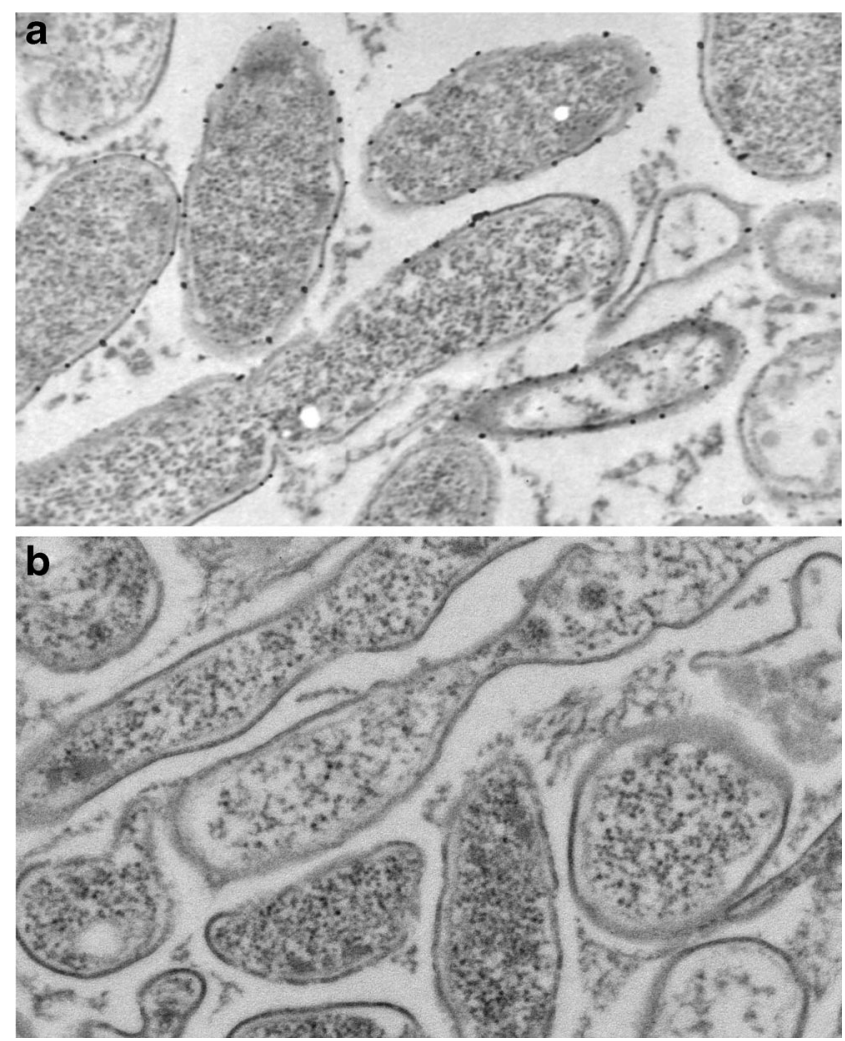

Fig. 3 Electron microscopic localization of enolase-like protein on the surface of Pseudomonas aeruginosa cells using 18-ng gold particles (magnification $\times 60,000$ ) . a Reaction with anti- $\alpha$-enolase antibodies. b Reaction with anti- $\alpha$-enolase antibodies after adding plasminogen 


\section{Discussion}

The outer membrane is the first line of defense for Gramnegative bacteria against toxic compounds. The bacterial surface components are immunologically important proteins because of their accessibility to host defense reaction. The presence of antibodies against alpha-enolase has been reported to be associated with a diverse range of bacterial infections. Antibodies against human and bacteria enolases have been demonstrated to have cross-reactivity, suggesting that pathogen-related enolase may be involved in the development of autoimmune diseases (Liu and Shih 2007; Terrier et al. 2007). The alpha-enolase obtained from human tissue could be used as a specific antigen for revealing circulating pathologic antibodies; furthermore, the production of specific rabbit antibodies would allow the evaluation of possible crossreactivity with $P$. aeruginosa surface enolase-like protein. This was the rationale for designing the method of obtaining alphaenolase from the organ which contains the enzyme in high concentration, i.e., the human kidney. During evolution, the human enolase preserved its highly conservative structure, with the enzyme homology between the placental mammals and other organisms reaching $50 \%$ (Piast et al. 2005; Seweryn et al. 2007). Therefore, some structural similarity could be anticipated between the human enolase and the enolase-like proteins expressed on the surface of $P$. aeruginosa external membranes, as described by Witkowska et al. (2005). In view of these studies, it seemed important to examine whether the enolase-like protein exhibited catalytic activity, despite the fact that $P$. aeruginosa is a non-fermenting bacteria using the Entner-Doudoroff pathway for oxidative catabolism. Our results have indicated that surface enolase-like protein does not have catalytic activity. This fact suggested that this protein has no catalytic center or that the center is unavailable to the substrate. In the present study, by electron microscopy, we have identified enolase-like protein on the surface of $P$. aeruginosa. We have confirmed the similarity of epitopes between the bacterial and human enolase. In fact, Bergmann et al. and Yavlovich et al. have identified alpha-enolase on the surface of Gram-positive bacteria such as Streptococcus pneumoniae, Streptococcus pyogenes, Staphylococcus aureus, and Mycoplasma fermentans (Bergmann et al. 2001; Yavlovich et al. 2007; Diaz-Ramos et al. 2012). We have identified for the first time on the surface of $P$. aeruginosa (Gram-negative bacteria) enolase-like protein. Moreover, we have obtained and purified this protein and described it. The study of localizing the enolase-like protein has been carried out on the surface of undisrupted bacterial cells by using antibodies against human alpha-enolase. The binding of enolase-like protein to plasminogen was demonstrated by electron microscopy in an in vitro study. Interestingly, the bacterial cells that have incubated with plasminogen did not exhibit any interaction with antibodies against human alpha- enolase. This result confirmed that the enolase-like protein on the surface of $P$. aeruginosa possesses the ability to bind to plasminogen. It was shown previously that surface proteins exhibit receptor-like properties in S. pneumoniae, Streptococcus mutans, Trichomonas vaginalis, and Bacillus anthracis (Pancholi and Fischetti 1998; Bergmann et al. 2001; Whiting et al. 2002; Ge et al. 2004; Agarwal et al. 2008; Mundodi et al. 2008). Plasminogen, in turn, allows it to invade tissues contributing to its pathogenicity. Proteolytic activation of plasminogen results in the formation of plasmin that degrades fibrin and ECM proteins (Diaz-Ramos et al. 2012). In conclusion, we have demonstrated for the first time, to our knowledge, that P. aeruginosa enolase-like protein has affinity for human plasminogen. Our results indicate that the surface enolase of a bacterium could be a key molecule in pathogenesis by facilitating bacterial interaction with host cells. Binding of plasminogen via enolase-like surface protein to the surface of $P$. aeruginosa may therefore facilitate invasion of host tissue.

Open Access This article is distributed under the terms of the Creative Commons Attribution License which permits any use, distribution, and reproduction in any medium, provided the original author(s) and the source are credited.

\section{References}

Agarwal S, Kulshreshtha P, Bambah Mukku D, Bhatnagar R (2008) $\alpha$-Enolase binds to human plasminogen on the surface of Bacillus anthracis. Biochim Biophys Acta 1784:986-994

Bergmann S, Rohde M, Chhatwal GS, Hammerschmidt S (2001) $\alpha$-Enolase of Streptococcus pneumoniae is a plasmin(ogen)-binding protein displayed on the bacterial cell surface. Mol Microbiol 40: 1273-1287

Campbell WN, Hendrix E, Cryz S Jr, Cross AS (1996) Immunogenicity of a 24-valent Klebsiella capsular polysaccharide vaccine and an eight-valent Pseudomonas O-polysaccharide conjugate vaccine administered to victims of acute trauma. Clin Infect Dis 23:179-181

Diaz-Ramos A, Roig-Borrellas A, Garcia-Melero A, Lopez-Alemany R (2012) $\alpha$-Enolase, amultifunctional protein: its role onpathophysiological situations. J Biomed Biotechnol 2012:156795

Doring G, Pier GB (2008) Vaccines and immunotherapy against Pseudomonas aeruginosa. Vaccine 26:1011-1024

Ge J, Catt DM, Gregory RL (2004) Streptococcus mutans surface alphaenolase binds salivary mucin MG2 and human plasminogen. Infect Immun 72:6748-6752

Govan JR, Deretic V (1996) Microbial pathogenesis in cystic fibrosis: mucoid Pseudomonas aeruginosa and Burkholderia cepacia. Microbiol Rev 60:539-574

Hancock RE, Speert DP (2000) Antibiotic resistance in Pseudomonas aeruginosa: mechanisms and impact on treatment. Drug Resist Updat 3:247-255

Jo JT, Brinkman FS, Hancock RE (2003) Aminoglycoside efflux in Pseudomonas aeruginosa: involvement of novel outer membrane proteins. Antimicrob Agents Chemother 47:1101-1111

Kim DK, Kim JJ, Kim JH, Woo YM, Kim S, Yoon DW, Choi CS, Kim I, Park WJ, Lee N, Jung SB, Ahn BY, Nam SW, Yoon SM, Choi WJ (2000) Comparison of two immunization schedules for a 
Pseudomonas aeruginosa outer membrane proteins vaccine in burn patients. Vaccine 19:1274-1283

Kinloch A, Tatzer V, Wait R, Peston D, Lundberg K, Donatien P, Moyes D, Taylor PC, Venables PJ (2005) Identification of citrullinated alpha-enolase as a candidate autoantigen in rheumatoid arthritis. Arthritis Res Ther 7:R1421-R1429

Lang H (2000) Outer membrane proteins as surface display systems. Int J Med Microbiol 290:579-585

Larbig M, Mansouri E, Freihorst J, Tummler B, Kohler G, Domdey H, Knapp B, Hungerer KD, Hundt E, Gabelsberger J, von Specht BU (2001) Safety and immunogenicity of an intranasal Pseudomonas aeruginosa hybrid outer membrane protein F-I vaccine in human volunteers. Vaccine 19:2291-2297

Lin J, Huang S, Zhang Q (2002) Outer membrane proteins: key players for bacterial adaptation in host niches. Microbes Infect 4:325-331

Liu KJ, Shih NY (2007) The role of enolase in tissue invasion and metastasis of pathogens and tumor cells. J Cancer Mol 3:45-48

Lomholt JA, Poulsen K, Kilian M (2001) Epidemic population structure of Pseudomonas aeruginosa: evidence for a clone that is pathogenic to the eye and that has a distinct combination of virulence factors. Infect Immun 69:6284-6295

Lopez-Alemany R, Longstaff C, Hawley S, Mirshahi M, Fabregas P, Jardi M, Merton E, Miles LA, Felez J (2003) Inhibition of cell surface mediated plasminogen activation by a monoclonal antibody against alpha-enolase. Am J Hematol 72:234-242

Mundodi V, Kucknoor AS, Alderete JF (2008) Immunogenic and plasminogen-binding surface-associated alpha-enolase of Trichomonas vaginalis. Infect Immun 76:523-531
Pancholi V (2001) Multifunctional alpha-enolase: its role in diseases. Cell Mol Life Sci 58:902-920

Pancholi V, Fischetti VA (1998) Alpha-enolase, a novel strong plasmin(ogen) binding protein on the surface of pathogenic streptococci. J Biol Chem 273:14503-14515

Piast M, Kustrzeba-Wojcicka I, Matusiewicz M, Banas T (2005) Molecular evolution of enolase. Acta Biochim Pol 52:507-513

Seweryn E, Pietkiewicz J, Szamborska A, Gamian A (2007) Enolase on the surface of prockaryotic and eukaryotic cells is a receptor for human plasminogen. Postepy Hig Med Dosw (Online) 61: 672-682

Seweryn E, Pietkiewicz J, Bednarz-Misa IS, Ceremuga I, Saczko J, Kulbacka J, Gamian A (2009) Localization of enolase in the subfractions of a breast cancer cell line. Z Naturforsch C 64:754 758

Terrier B, Degand N, Guilpain P, Servettaz A, Guillevin L, Mouthon L (2007) Alpha-enolase: a target of antibodies in infectious and autoimmune diseases. Autoimmun Rev 6:176-182

Whiting GC, Evans JT, Patel S, Gillespie SH (2002) Purification of native alpha-enolase from Streptococcus pneumoniae that binds plasminogen and is immunogenic. J Med Microbiol 51:837-843

Witkowska D, Pietkiewicz J, Szostko B, Danielewicz R, Maslowski L, Gamian A (2005) Antibodies against human muscle enolase recognize a $45-\mathrm{kDa}$ bacterial cell wall outer membrane enolase-like protein. FEMS Immunol Med Microbiol 45:53-62

Yavlovich A, Rechnitzer H, Rottem S (2007) Alpha-enolase resides on the cell surface of Mycoplasma fermentans and binds plasminogen. Infect Immun 75:5716-5719 